Ann. Biol. anim. Bioch. Biophys., 1979, 19 (4 B), 1219-1229.

\title{
Origin of the somatic cells in the rat gonad : An autoradiographic approach
}

\author{
par H. MERCHANT-LARIOS \\ with the technical assistance of B. CENTENO-URRUIZA \\ Departamento de Biología del Desarrollo, Instituto de Investigaciones Biomédicas \\ Apartado Postal 70228, México 20, D. F., México.
}

Summary. Gonads from rats of 11 and 12 days of gestation that had been given a pulse of ${ }^{3} \mathrm{H}$-thymidine were studied at different times using autoradiographic techniques. When the animals, were labeled before the formation of the gonadal blastema (11 days), the percentage of labeled cells in this structure was greater than in the coelomic epithelium and mesenchyme. However, when ${ }^{3} \mathrm{H}$-thymidine was injected after the gonadal blastema was already established (12 days), very few of these cells took up the compound; they remained in this condition until the sexual differentiation of the gonad. From this characteristic, which is an indication of the early differentiation of the blastemal cells, one may conclude that the seminiferous cords arise from this initial cellular line. On the other hand, there appears to be a contribution of coelomic epithelial cells during the formation of the sex cords in the ovary.

\section{Introduction.}

The origin of the somatic cells which form the mammalian gonad has been a topic of heated controversy for many years. Basically, there are three interpretations :

a) Witschi (1951) suggests that the indifferent gonad arises from two rudimentary embryonic tissues : the cortex, product of the proliferation of the coelomic epithelial cells, and the medulla, arising from the cells which form the so-called mesonephric blastema. He maintains that the fate of each of these primordia is already determined, such that the former is the precursor of the ovary and the latter, of the testicle.

b) The gonad is formed as a result of two consecutive proliferations of the coelomic epithelium. The first gives rise to the seminiferous cords and the second to the cortex of the ovary (Gillman, 1948).

c) The indifferent gonad is formed from both the coelomic epithelium and the adjacent mesenchyme. The proliferation of these tissues gives rise to a blastema from which the sex cords as well as the gonadal stroma are organized during a later stage of development (Gruenwald, 1942 ; Pinkerton et al., 1961).

Recent studies using high resolution techniques seem to support the third interpretation (Merchant, 1975 ; Pelliniemi, 1976). Nevertheless, aside from several classical 
experimental studies which are not easy to interpret due to technical difficulties intrinsic to the manipulation of the mammalian gonad (Martinovich, 1938), we know of no morpho-dynamic study which offers further information about this unresolved problem.

The fechnique of autoradiography by which one or several generations of cells are labeled during the morphogenesis and differentiation of various tissues and organs has been very useful in tracing the origin of the cells which form these structures. In the present work, we have undertaken the study of the embryological origin of the somatic cells of the rat gonad using this technique.

\section{Materials and methods.}

Female Wistar rats were placed with fertile males for one night and vaginal smears were taken the following morning. Those in which spermatozoids were found were considered to be in Day 0 of gestation. The pregnant animals were given an intraperitoneal injection of ${ }^{3} \mathrm{H}$-thymidine $(1.5 \mu \mathrm{Ci} / \mathrm{g}$ body weight, Spec. Act. $20 \mathrm{Ci} / \mathrm{mmol})$ on Day 12 and were killed at $0.5,3,6,12,18,24,30$ and $48 \mathrm{~h}$. The same treatment was also carried out on Day 11 and the fetuses were studied $0.5,12$ and $24 \mathrm{~h}$ later. The caudal region of each fetus was dissected, the viscera were discarded and the dorsal part containing the gonads was rapidly placed in a fixative composed of 2.5 p. 100 , glutaraldehyde-1 p. 100 paraformaldehyde in $0.1 \mathrm{M}$ cacodylate buffer. The tissues were then post-fixed with 1 p. $100 \mathrm{OsO}_{4}$ in Zetterquist buffer, dehydrated with ethanol and embedded in Epon 812.

Semi-thin sections $(2 \mathrm{~m} \mu)$ from the urogenital zone were made and placed on a microscope slide covered with a 0.5 p. 100 gelatin solution. In order to avoid counting the same cells twice due to the thinness of the sections, the following strategy was used : 10 serial sections were made and placed on a slide, the following 10 sections were discarded and the next 10 sections were again mounted on another slide. This operation was repeated 4 times so that a total of 40 sections was obtained for each fetal gonad. A minimum of 5 fetuses ( $8-10$ gonads) were studied at each time using this procedure.

The slides with the sections were covered with Kodak NTB2 emulsion and exposed for 20 or 30 days following standard autoradiographic techniques. The sections were

FIG. 1. - Genital ridge of a 12-day embryo treated $24 \mathrm{~h}$ before with ${ }^{3} \mathrm{H}$-thymidine. The inner epithelial cells (IEC) appear more labeled than the mesenchymal (Mc) and coelomic epithelial (CE) cells. $\times 600$.

FIG. 2. - Gonod of a 12-day embryo $30 \mathrm{~min}$. after ${ }^{3} \mathrm{H}$-thymidine. The labeled cells are found in the mesenchyme $(\mathrm{Mc})$, coelomic epithelium (CE) and mesonephric tubule (MN). Almost no labeled cells are seen among the inner epithelial cells (IEC). $\times 240$.

FIG. 3. - Photomicrograph of a 12-day embryo treated with ${ }^{3} \mathrm{H}$-thymidine $3 \mathrm{~h}$ before fixation. Cells of the surface epithelium and of the mesenchyme appear highly labeled. Most of the primordial germ cells are also labeled; however, the somatic cells around them practically did not take the label. Part of a mesonephric tubule $(\mathrm{MN})$ undergoing degeneration is shown. $\times 380$. 


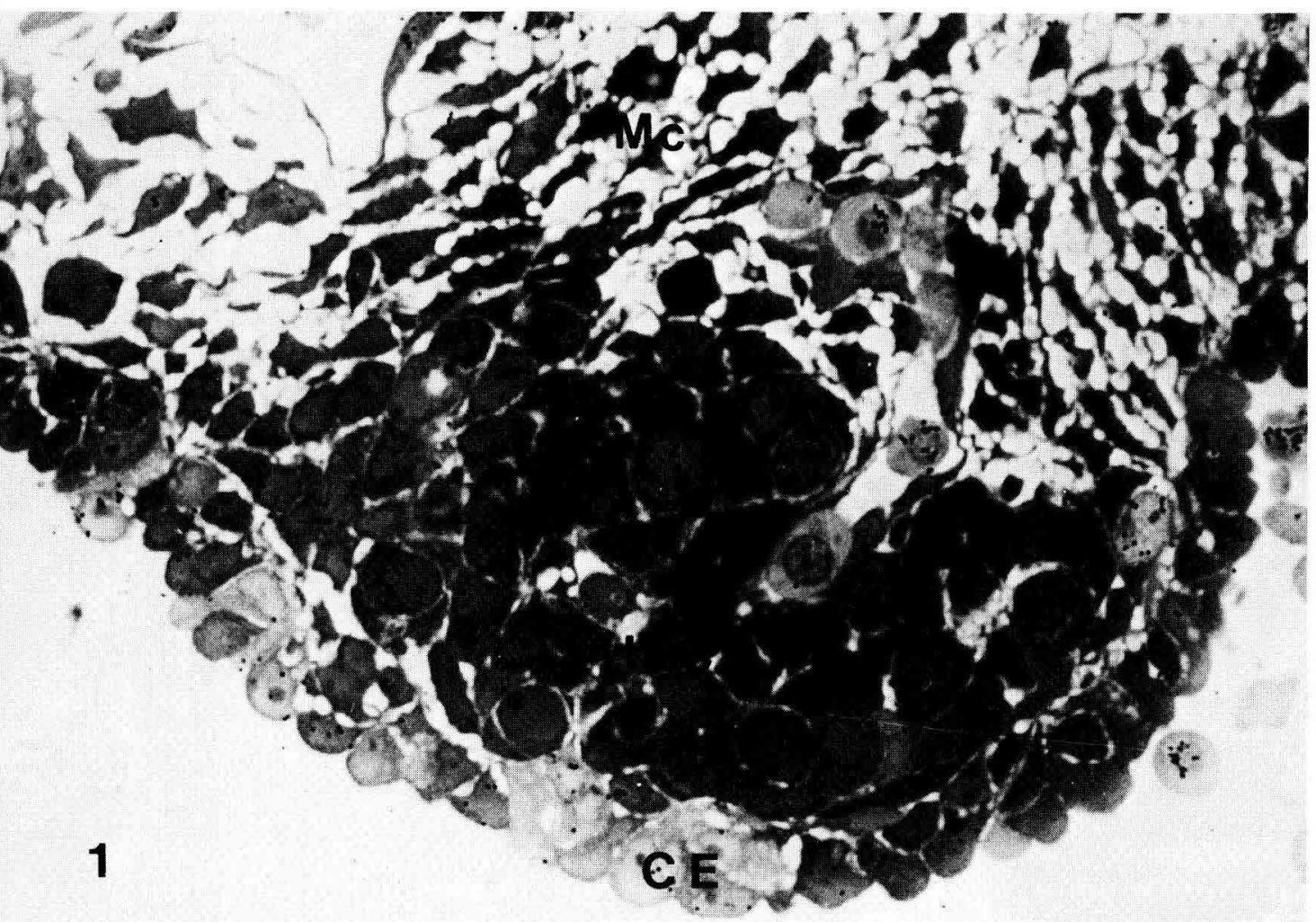


then dyed with Azure II and methylene blue (Richardson, Jarett and Finke, 1960), mounted in L 15 medium (Zeiss Co.) and observed with phase contrast optics. The number of photographs taken of each gonad was determined by its size, and photographic montages were made from which the labeled cells were counted.

The gonad was divided into 4 cellular populations : coelomic epithelium, internal epithelium, primordial germ cells and surrounding mesenchyme. Counting was facilitated by placing a glass on top of the montage and marking, one by one, the cells of each zone with a colored pen. The percentage of cells so marked of the total population was then calculated.

\section{Results.}

Series labeled from Day 11 of gestation. - Only the coelomic epithelium and mesenchyme are evident in the urogenital zone soon after injection ( 0.5 to $12 \mathrm{~h}$ ). Approximately 25 p. 100 of the cells are labeled in these two regions, similar to the percentage found in the neighboring mesonephric tubules which contain numerous cells in the process of degeneration. At $24 \mathrm{~h}$ post-injection ( 12 days of gestation), the genital ridge, in which the percentage of labeled cells in the internal epithelium ( 35 p. 100) surpasses that of the coelomic epithelium (15 p. 100) and mesenchyme (20 p. 100), may already be observed (fig. 1).

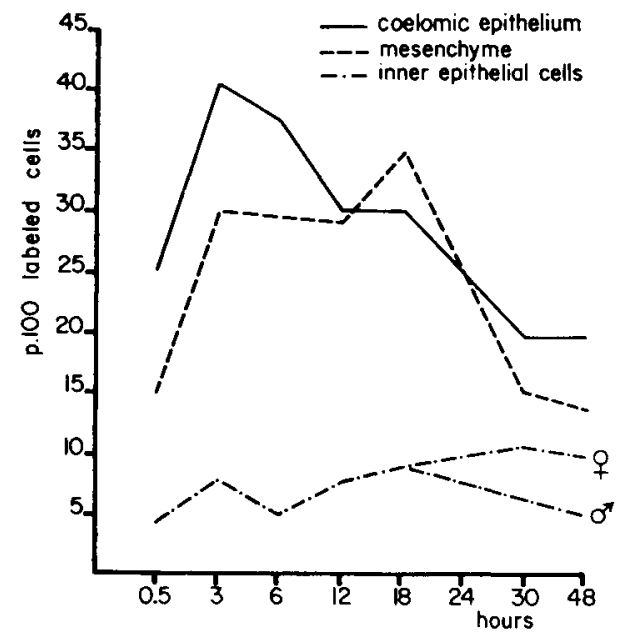

GRAPH. 1 - Labeled somatic cells in the gonadal region of rot fetus ofter ${ }^{3} \mathrm{H}$-thymidine injection on day 12 of gestation

Series labeled from Day 12 of gestation. - The results have been summarized in graph 1 which shows the three regions occupied by somatic cells during this stage of development : coelomic epithelium, surrounding mesenchyme and internal epithelium-

FIG. 4. - Photographic montage of a gonad fixed $6 \mathrm{~h}$ after ${ }^{3} \mathrm{H}$-thymidine. The coelomic epithelium (CE), the mesenchyme (Mc) and the mesonephros (MN) contain numerous labeled cells. In the inner epithelial tissue only a few of the somatic cells are labeled. On the other hand, most of the germ cells are labeled. The degeneration of several mesonephric cells is evident. $\times 600$. 


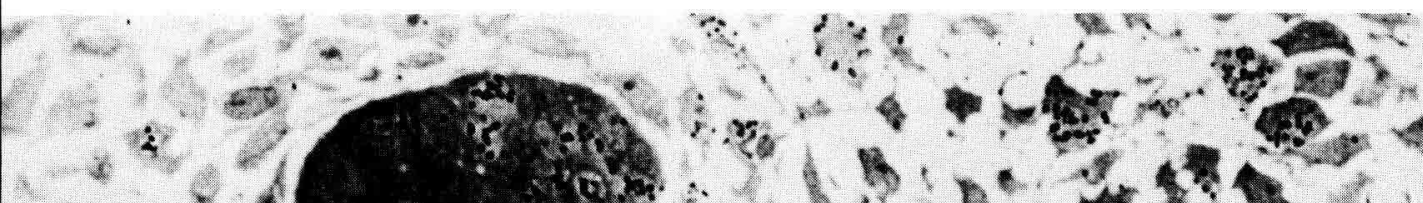

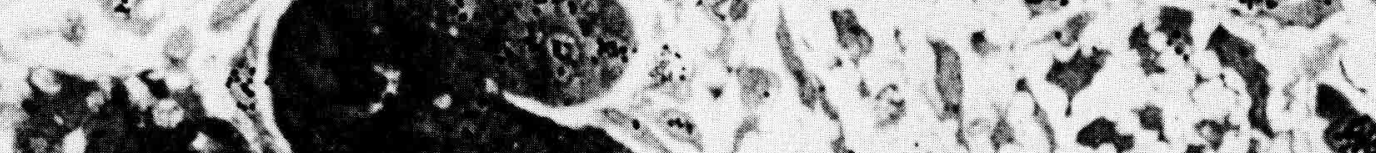

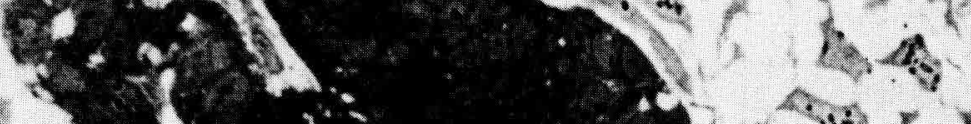
minc.

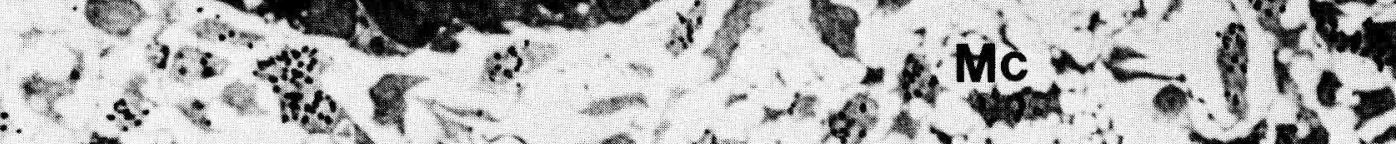

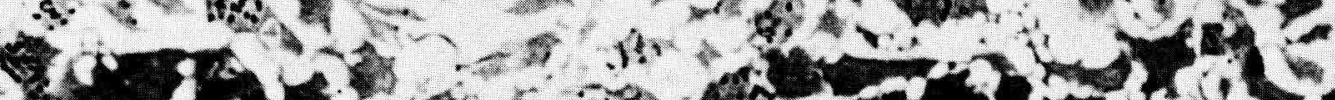

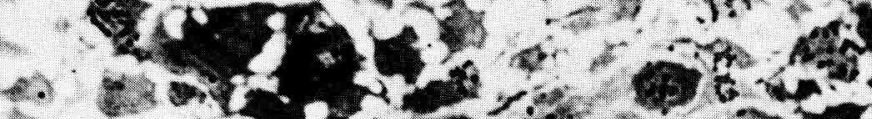

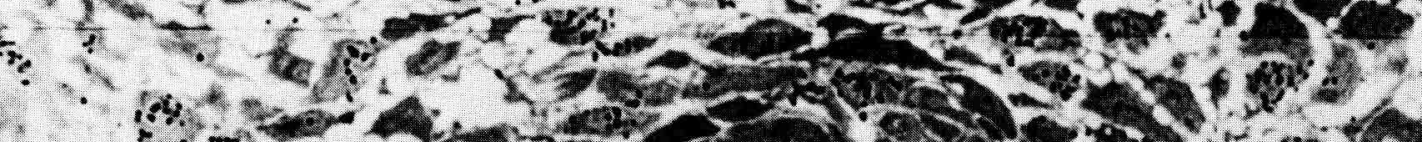

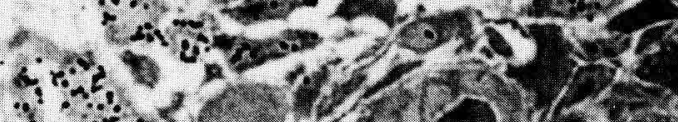

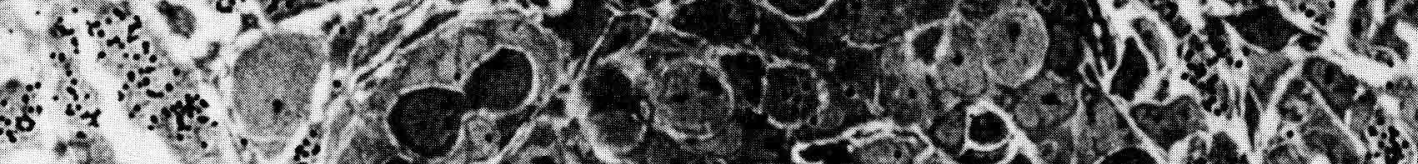

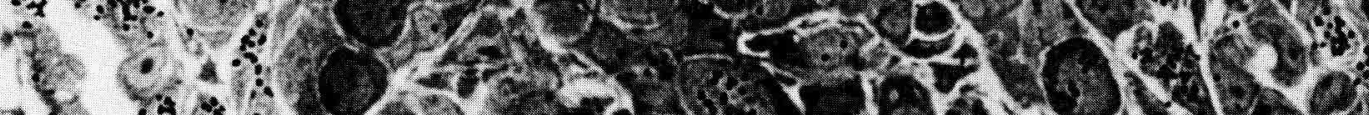

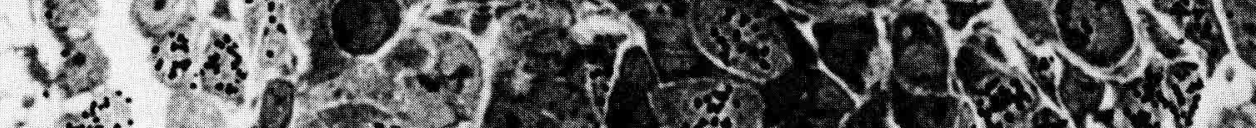

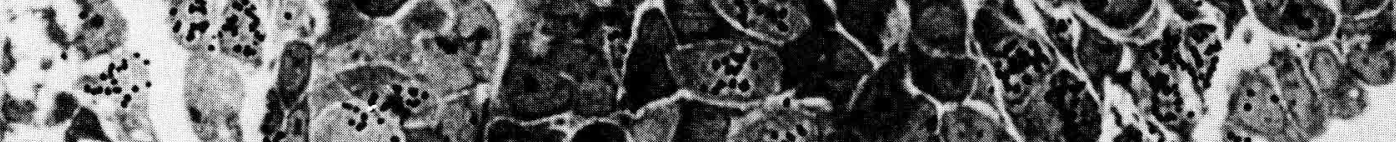

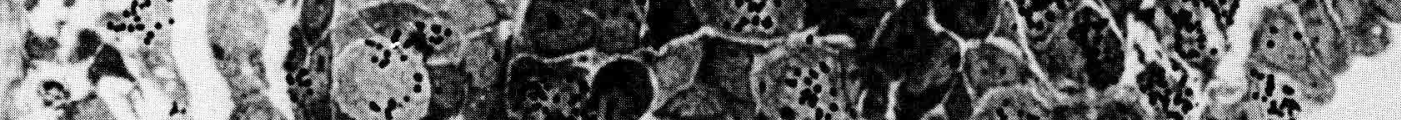

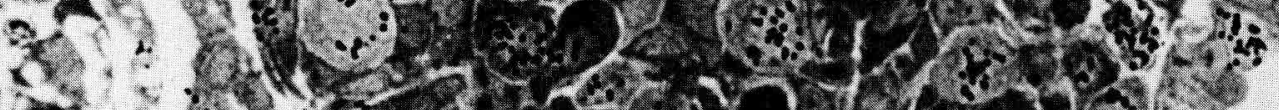
$\therefore$ is

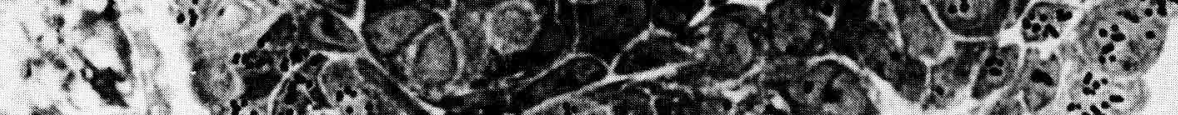

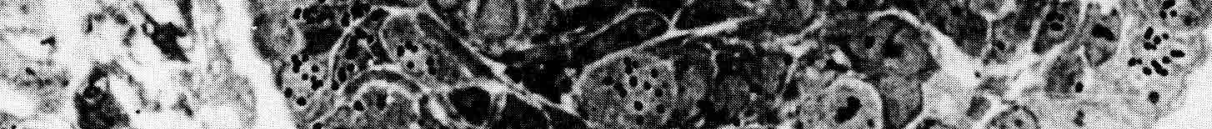

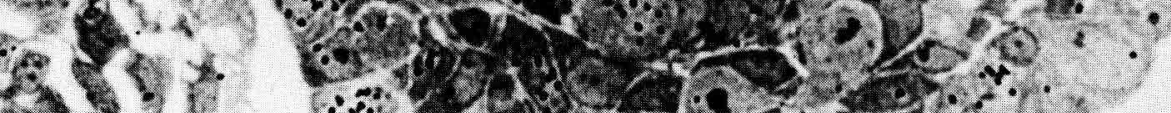

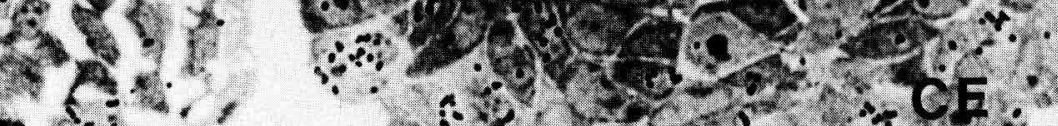
$\left\{\begin{array}{l}0 \\ 6\end{array}\right.$ 
which make up the genital ridge. The percentage of labeled cells is always greater in the former two tissues than in the latter. The maximum number of labeled cells in the coelomic epithelium (40 p. 100) and mesenchyme (35 p. 100) is found between 3 and $18 \mathrm{~h}$ post-injection, while the minimum is found at 30 (10 p. 100) and $48 \mathrm{~h}(12 \mathrm{p} .100)$, respectively. The internal epithelium remains poorly labeled during the first $18 \mathrm{~h}$ (less than 10 p. 100). The percentage of labeled cells in this population varies when sexual differentiation is initiated at $24 \mathrm{~h}$ post-injection (13 days of gestation) according to whether the gonad is an ovary (10 p. 100) or a testicle (5 p. 100).

Figure 1 depicts a gonad of 12 days of gestation which has been injected $24 \mathrm{~h}$ before. It is evident that the proportion of labeled cells in the internal epithelium is considerably elevated in comparison with that found in this same population when the treatment is initiated on Day 12 (figs 2, 3, 4).

Parts of mesonephric tubules from embryos treated on Day 12 of gestation and fixed at 0.5, 3 and $6 \mathrm{~h}$ post-injection may be observed in figures 2, 3 and 4 . Figure 2 shows a healthy-looking mesonephric tubule with heavily labeled cells, while clear degenerative signs are evident in the mesonephric cells in figures 3 and 4 . The epithelial cords are just becoming visible in the indifferent gonad depicted in figure 4.

Figures 5 and 6 show a testicle and an ovary from the Day 12 series fixed at 24 and $30 \mathrm{~h}$ post-injection, respectively. The intracordonal cells (internal epithelium) of the testicle are sparsely labeled, while there is an abundance of marked cells in the superficial epithelium as well as in the surrounding mesenchyme (fig. 5). In contrast, the incorporation of labeled cells in the internal epithelium, especially in areas close to the superficial epithelium, is quite evident in the ovary; nevertheless, the somatic cells in the deepest layers remain poorly labeled (fig. 6).

\section{Discussion.}

The results of this study suggest that the establishment and sexual differentiation of the gonad take place through a series of cellular events more complex than those previously suggested by purely morphological studies.

This work is based on the well-demonstrated fact that proliferating cells incorporate ${ }^{3} \mathrm{H}$-thymidine during phase $\mathrm{S}$ of their cellular cycle (Baserga, 1965). The duration of this process varies according to the cellular type under consideration. Thus, if the marker is available for only a limited period of time, the cells with shorter cycles will have a greater probability of being labeled. When studying two or more cellular populations, each occupying a different « compartment» in a developing organ, it would only be possible to distinguish the movements of labeled cells from one «compartment $)$ to another when there is an initial significant difference in the percentage of labeled cells in each « compartment ».

FIG. 5. - Testicle of a 13-day embryo treated $24 \mathrm{~h}$ before with ${ }^{3} \mathrm{H}$-thymidine. The centrally located seminiferous cords contain highly labeled germ cells and only a few somatic cells appear labeled. The surface epithelium and the mesenchyme which surrounds the cords have many labeled cells. Reduced photographic montage. 


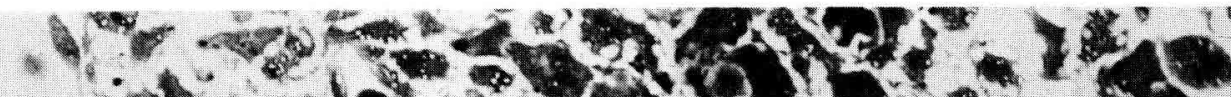

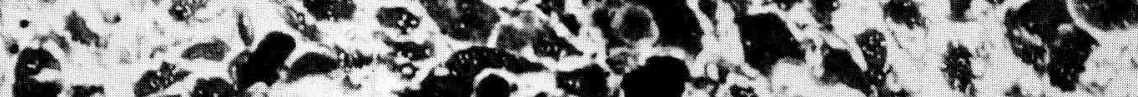

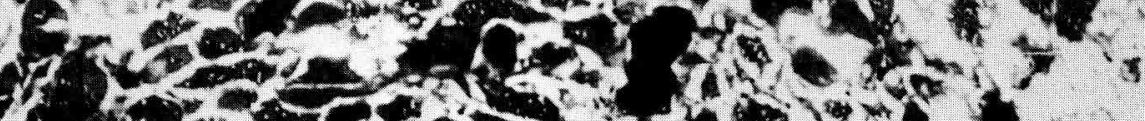

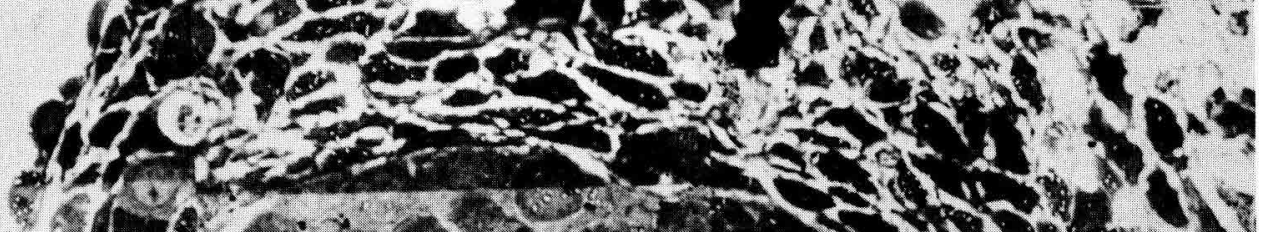

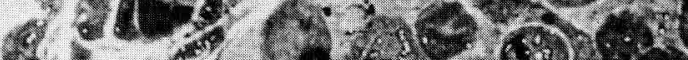

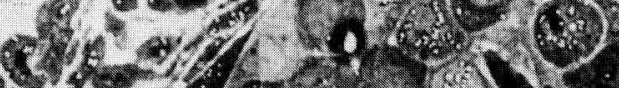

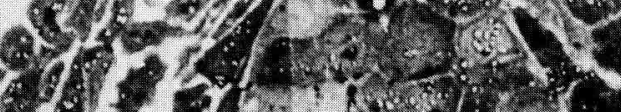

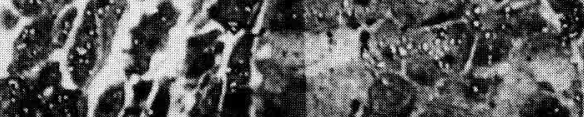

ifin

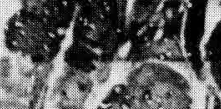

$x^{2}+2 \sin ^{2}$

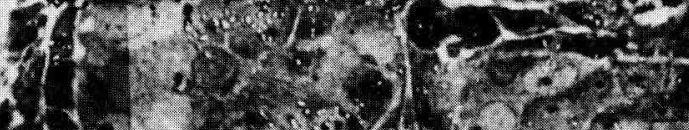

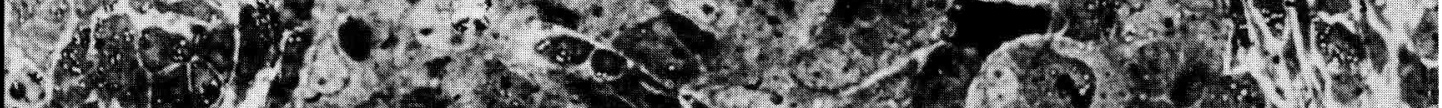
a

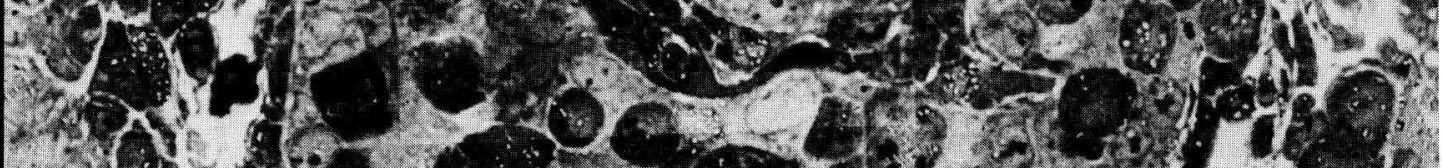

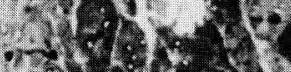

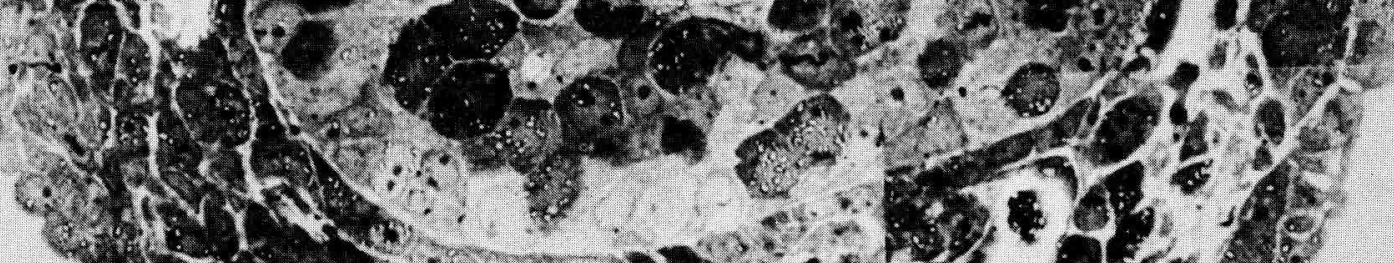

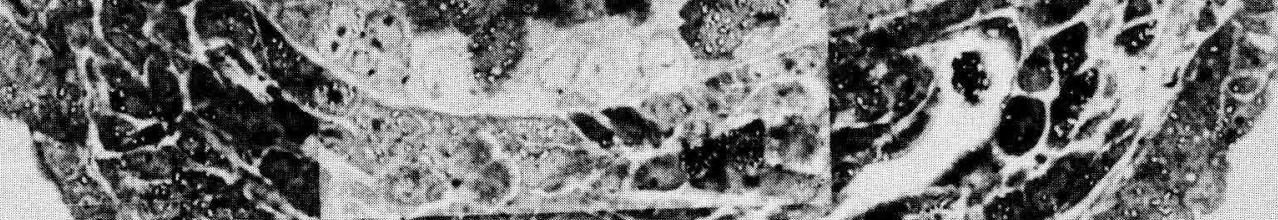

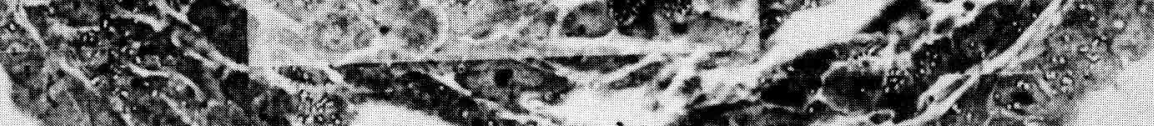

$$
\begin{aligned}
& \text { (j) }
\end{aligned}
$$

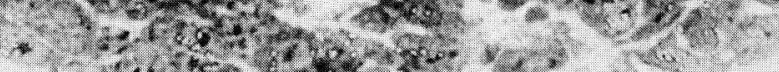

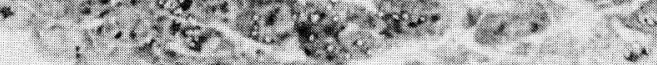

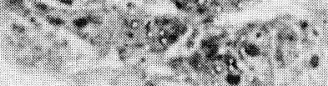


In the case of the gonad, there basically exists two tissues (" compartments "), the epithelia and the stroma, separated by a thin basal lamina. The former give rise to the "sex cords " which contain the germ cells, as well as to the precursors of the Sertoli cells in a testicle, or to granular cells in an ovary. Connective tissue, Leydig cells, the thecas and the so-called interstitial gland have their origin in the stroma.

If the criterion for detecting the movement of cells from one "compartment " to the other is accepted as valid, it can be seen that it is only possible to follow the dynamics of the formation of the "sex cords " in this work, since there are no significant differences in the percentages of labeled cells in the coelomic epithelium and mesenchyme.

It has not been possible to precisely determine the origin of the initial cells of the internal epithelium since a similar percentage of cells of the mesenchyme and coelomic epithelium are labeled before it appears. However, it is clear that a much higher percentage of cells are labeled in the former population than in the latter two, in embryos of 12 days of gestation to which the marker was administered $24 \mathrm{~h}$ previously (on Day 11). This finding together with those from earlier ultrastructural studies (Merchant, 1975 ) suggest that both the coelomic epithelium and the mesenchyme could contribute cells which form the primordium of the internal epithelium.

The early association established between some mesonephric fubules and the developing gonad has been reported by Brambell (1928) in the mouse, and by Torrey (1943) and Roosen-Runge (1961) in the rat. However, the possibility that the former structures might contribute to the formation of the internal epithelium once it has been established is difficult to support. This is due to previous observations (Jost, 1972 ; Merchant, 1975), as well as to those made in this study, of a massive degeneration of the cells composing the few mesonephric tubules that are sifuated near the gonadal region on day 12 of gestation (see figs. 3 and 4). Moreover, a great number of healthylooking mesonephric cells appear labeled whereas the inner epithelial cells remain poorly labeled (fig. 2).

The results obtained after ${ }^{3} \mathrm{H}$-thymidine was administered from Day 12 of gestation suggest that there exists a clear decrement in the capacity of the cells of the internal epithelium to incorporate the marker in comparison with those of the other two "compartments", although there are no obvious morphological differences when observed under the electron microscope (Merchant, 1975). While this could be due to an early metabolic differentiation or to an altered permeability of the membrane of the cells of the internal epithelium, it is more probable that phase G1 or G2 of their cellular cycle is longer in duration, thus diminishing the availability of ${ }^{3} \mathrm{H}$-thymidine for uptake.

An early differentiation resulting from a change in the location of the cells appears to be a common mechanism in other developing embryonic systems (Hillman, Sherman and Graham, 1972 ; Wolpert, Lewis and Summerbell, 1975). The relationship bet-

FIG. 6. - Rat embryonic ovary treated $30 \mathrm{~h}$ before with ${ }^{3} \mathrm{H}$-thymidine. Only a few of the innermost somatic cells appear labeled; the germ cells and most of the surrounding cells are highly labeled. Reduced photographic montage. 


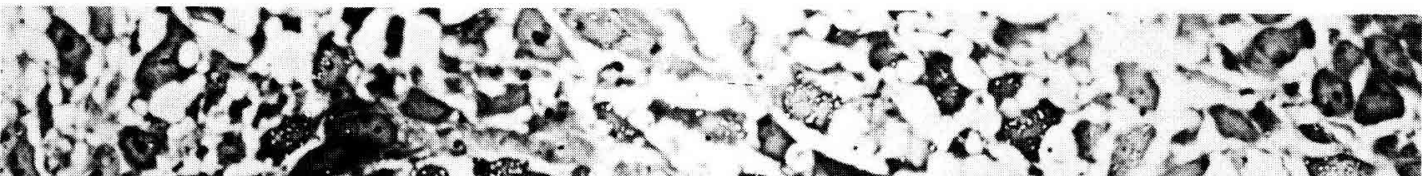

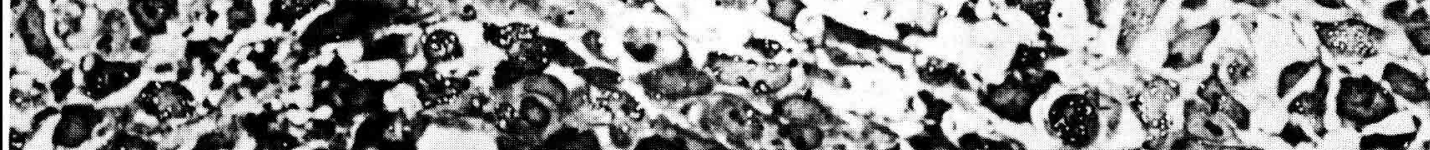

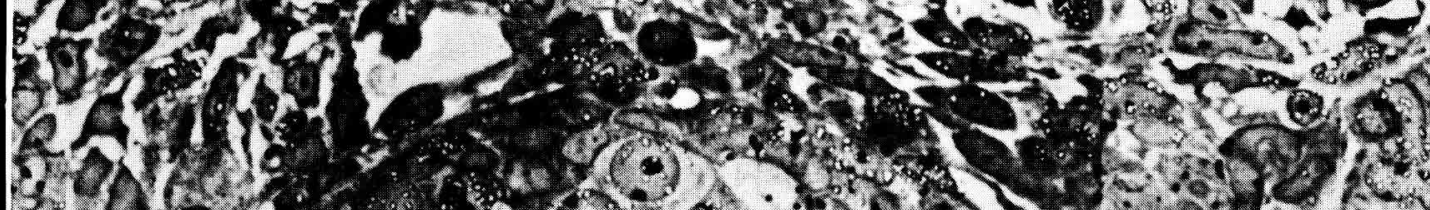

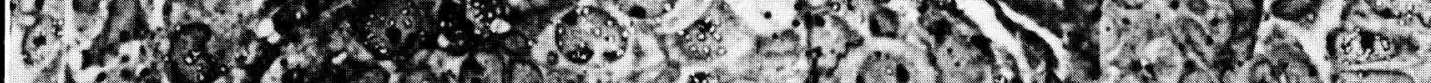

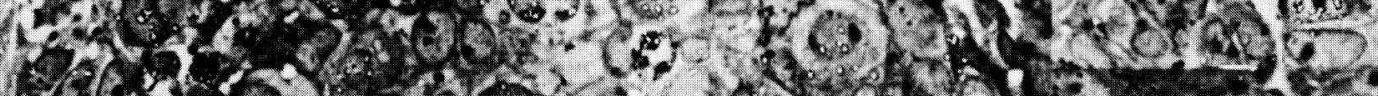

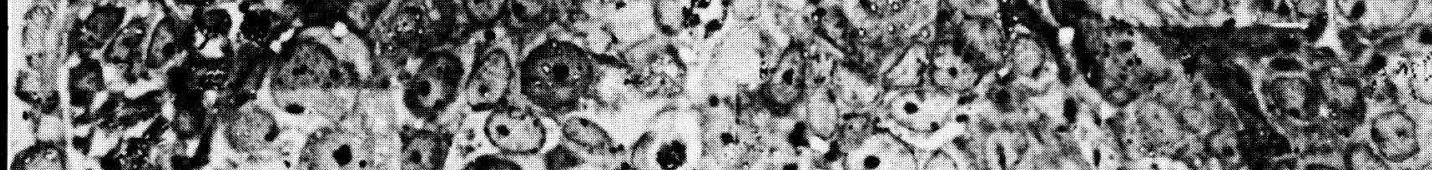

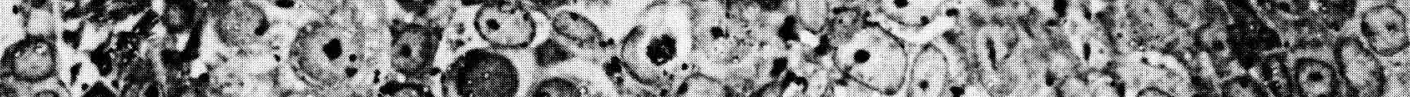

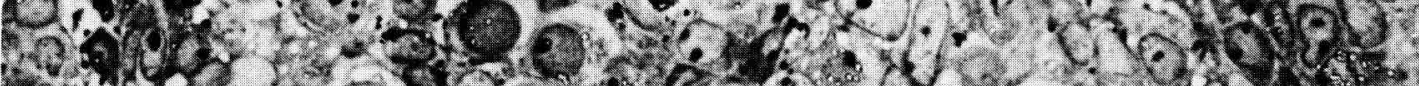

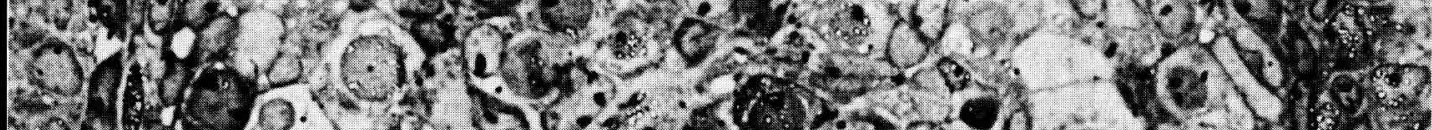

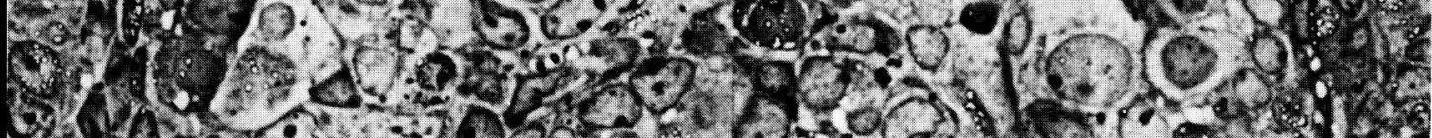

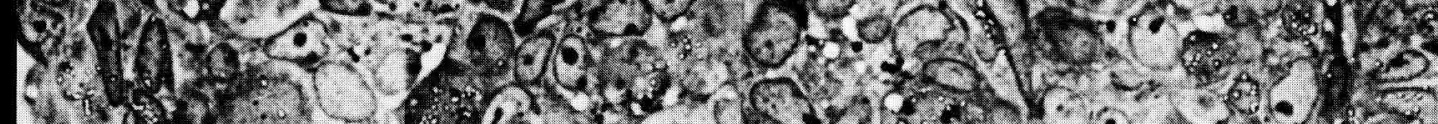

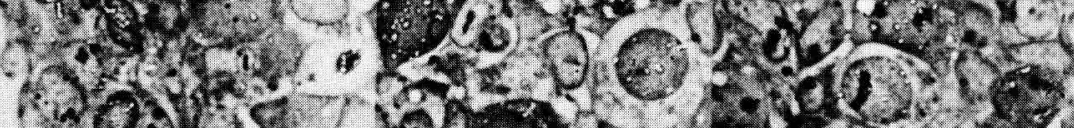

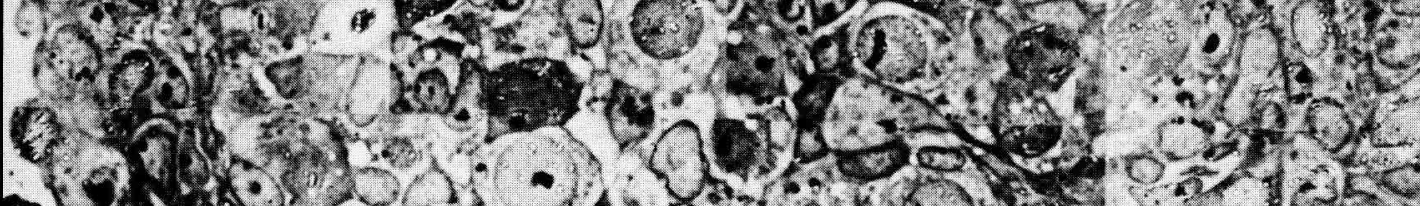

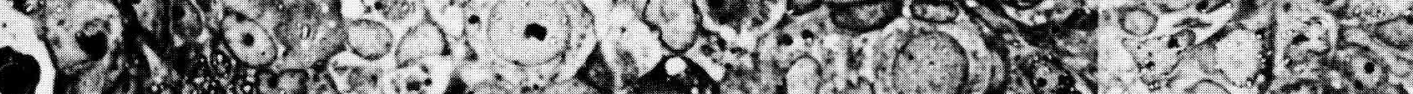

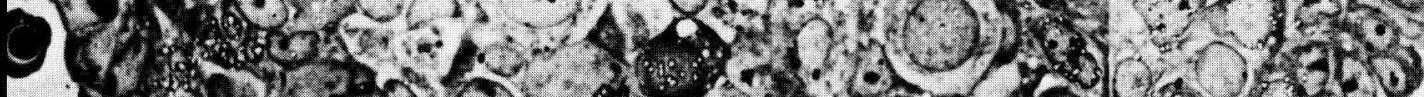

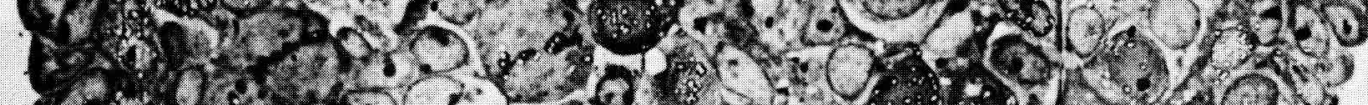

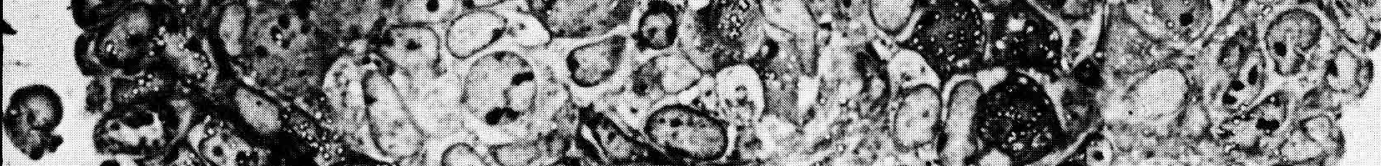

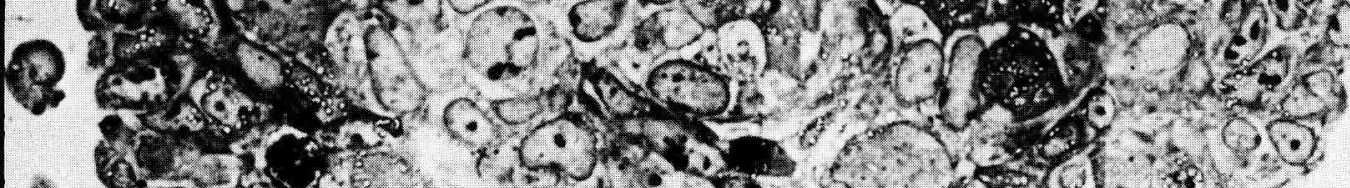

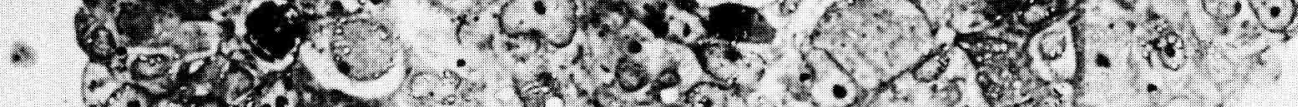

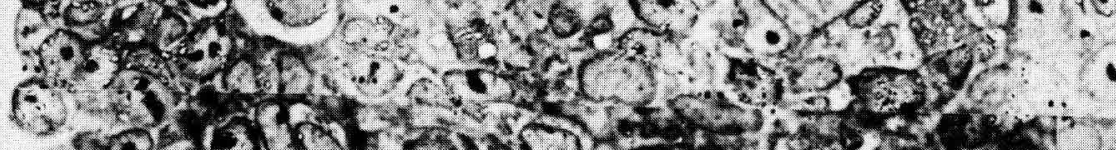

sof (2)

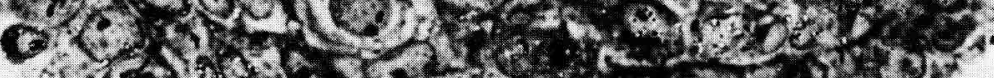

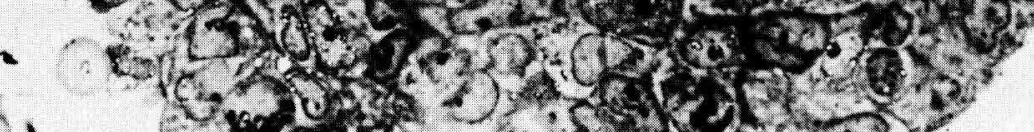

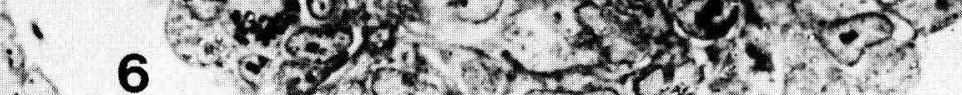

4

$$
\begin{aligned}
& \text { (c) } \\
& \text { (1) } x^{2}: x^{2} \cdot 4: \\
& \text { - }
\end{aligned}
$$


ween cellular differentiation and control of the cellular cycle has been reported during the embryonic development of various organs as well (Dienstman and Holtzer, 1975 ; Tsanev, 1975). Therefore, it is not surprising that there may function mechanisms of control in the establishment of the indifferent gonad similar to those found in other organs.

The early differentiation of the cells of the internal epithelium permit additional information to be obtained concerning the later growth of the sex cords. The low level of labeling maintained during the first $24 \mathrm{~h}$ in all the embryos in which ${ }^{3} \mathrm{H}$-thymidine was administered on Day 12 of gestation suggests that the growth of the initially formed internal epithelium takes place in a similar manner in both sexes. However, this epithelium soon separates from the coelomic epithelium in the testis and continues its development independently. In ovaries, on the other hand, the notable increase in the number of labeled cells in the internal cords suggests the passage of cells originally located in the heavily labeled coelomic epithelium to the internal epithelium, thereby contributing to its growth. Although the mesenchyme could be a source of cells as well, the presence of a continuous basal lamina, observable with the electron microscope in ovaries from Day 14 embryos (Merchant, 1975) makes this improbable.

\section{Conclusion.}

1. - The present study does not solve the problem of the origin of the first inner epithelial cells.

2. - The inner epithelial cells, once present, manifest a first differentiation by their poor ability to incorporate ${ }^{3} \mathrm{H}$-thymidine. This fact is interpreted as evidence of a longer cell cycle in these cells.

3. - The inner epithelial cells soon become independent of the coelomic epithelium and form the seminiferous cords in the male gonads. In the female, however, the inner epithelial tissue grows by proliferation of its own cells (poorly labeled) and by the addition of cells from the coelomic epithelium (heavily labeled).

4th Workshop on « Development and maturation of the reproductive organs and functions $》$ Luynes, France, octobre 1978.

Acknowledgments. - This work was supported in part by Grant No 48.176.1.76 from PLAMIR (Programa Latinoamericano de Investigación en Reproducción Humana). The author wishes to thank Ms. Marcella Vogt for her excellent editorial assistance.

Résumé. Les gonades de rats à 11 et 12 jours de gestation ayant reçu un « pulse » de thymidine tritiée ont été étudiées à différentes reprises en utilisant les techniques autoradiographiques. Quand les animaux étaient $m$ is en expérience avant la formation des blastèmes gonadiques ( 11 jours), le pourcentage de cellules marquées dans cette structure était supérieur à celui dans l'épithélium cœlomique et dans le mésenchyme. Cependant, quand la thymidine tritiée a été injectée après que le blastème gonadique soit établi (12 jours), très peu de ces cellules ont incorporé ce composé ; elles restent dans cet état jusqu'à la différenciation sexuelle de la gonade. A partir de cette caractéristique, qui est une indica- 
tion de la différenciation précoce des cellules du blastème, on peut conclure que les cordons séminifères proviennent de cette lignée cellulaire initiale. Par ailleurs, ceci paraît être une contribution des cellules cœlomiques épithéliales pendant la formation des cordons sexuels dans l'ovaire.

\section{References}

BASERGA R., 1965. The relationship of the cell cycle to fumor growth and control of cell division : a review. Cancer Res., 25, 581-595.

BRAMBELL F. W. R., 1928. The development and morphology of the gonads of the mouse. II. The development of the Wolffian body and ducts. Prac. roy. Soc. B, 102, 206-221.

DIENSTMAN S. R., HOLTZER H., 1975. Myogenesis : a cell lineage interpretation, 1-26. In REINERT J., HOLTZER H., Cell cycle and cell differentiation, Springer-Verlag, New York.

GILLMAN J., 1948. The development of the gonads in man, with a consideration of the role of fetal endocrines and the histogenesis of ovarian tumors. Contr. Embryol. Carneg. Inst., 32, 81-131.

GRUENWALD P., 1942. The development of the sex cords in the gonads of man and mammals. Amer. J. Anat., 70, 359-368.

HILLMAN N., SHERMAN M. I., GRAHAM C., 1972. The effect of spatial arrangement on cell determination during mouse development. J. Embryol. exp. Morph., 28, 263-278.

JOST A., 1972. Données préliminaires sur les stades initiaux de la différenciation du testicule chez le rat. Arch. Anat. micr. Morph. exp., 61, 415-438.

MARTINOVICH P. N., 1938. The development in vitro of the mammalian gonad, ovary and ovogenesis. Proc. roy. Soc. B, 125, 232-247.

MERCHANT H., 1975. Rat gonadal and ovarian organogenesis with and without germ cells. An ultrastructural study. Develop. Biol., 44, 1-21.

PELLINIEMI J. L., 1976. Ulitrastructure of the indifferent gonad in male and female pig embryos. Tissue Cell, 8, 163-174.

PINKERTON J. H. M., MCKAY D. G., ADAMS E. C., HERTIG A. T., 1961. Development of the human ovary. A study using histochemical techniques. Obstet. Gynec., 18, 152-181.

RICHARDSON K. C., JARETT L., FINKE E. H., 1960. Embedding in epoxy resins for ultrathin sectioning in electron microscopy. Stain Technol., 35, 313-322.

ROOSEN-RUNGE E. C., 1961. The rete testis in the albino rat : its structure, development and morphological significance. Acta anat. (Basel), 45, 1-30.

TORREY T. W., 1943. The development of the urogenital system in the albino rat. I. The kidney and its ducts. Amer. J. Anat., 72, 113-147.

TSANEV R., 1975. Cell cycle and liver function, 197-248. In REINERT J., HOLTZER H., Cell cycle and cell differentiation, Springer-Verlag. New York.

WITSCHI E., 1951. Embryogenesis of the adrenal and the reproductive glands. Recent Progr. Hormone Res., 6, 1-27.

WOLPERT L., LEWIS J., SUMMERBELL D., 1975. Morphogenesis of the vertebrate limb, 95-130. In Cell Patterning. CIBA Found. Symp. 29, Elsevier, Excerpta med., North-Holland, Amsterdam. 